\title{
ARTICLE
}

\section{Vegetative anatomy of Tabernaemontana alternifolia L. (Apocynaceae) endemic to southern Western Ghats, India}

\author{
Yuvarani Seenu, Koshila Ravi Ravichandran, Anaswara Sivadas, Balachandar \\ Mayakrishnan*, Muthukumar Thangavelu
}

Root and Soil Biology Laboratory, Department of Botany, Bharathiar University, Coimbatore 641 046, Tamil Nadu, India

\begin{abstract}
The anatomical description of vegetative parts of Taberenaemontana alternifolia L. belonging to the family Apocynaceae was investigated in the present study. The leaves of $T$. alternifolia is hypostomatic with paracytic stomata, uniseriate epidermis made up of thin-walled parenchymatous cells covered by thin cuticle on both adaxial and abaxial surfaces. The hypodermis comprises of angular collenchyma cells. Mesophyll is dorsiventral containing silica bodies and vascular bundles are bicollateral. The petiole is flattened adaxially and arch-shaped abaxially with a uniseriate epidermis covered by a thin cuticle. The hypodermis is 7-8 layered angular collenchyma cells consisting of laticifers and parenchymatic, cortical layers consisting of silica bodies and thick-walled fibers and U-shaped bicollateral vascular bundles. Secondary growth in stems is characterized by the formation of periderm and thick-walled fibers in the vascular tissues. Bicollateral vascular bundles are covered by sclerenchymatous patches, parenchymatous cortex and pith consist of fibers, laticifers and silica bodies. The root possess unicellular root hairs, compactly arranged thin-walled uniseriate epidermis, 16-18 layered cortex containing silica bodies and fibers, indistinct endodermis, radially arranged vascular bundles and 14-16 arched xylem. Pitted water-storage cells are present in the conjunctive tissue. Lignin deposition was observed in the root stelar region and pith is absent.
\end{abstract}

Acta Biol Szeged 63(2):185-193 (2019)

\author{
KEY WORDS \\ anatomical features \\ collenchymas \\ fibers \\ laticifers \\ secondary growth
}

\section{Introduction}

The genus Tabernaemontana belonging to the family Apocynaceae comprises of around 102 species occurring throughout the tropical and also in some subtropical regions of the world (Van Beek et al. 1984). Tabernaemontana includes shrubs or small deciduous trees bearing white latex, dichotomously branched stem and opposite leaves. Tabernaemontana alternifolia L. (= Tabernaemontana heyneana Wall) is a small tree growing up to $8 \mathrm{~m}$ tall and produce milky white latex (Ignacimuthu et al. 2006). It is commonly found in open forests of Western Ghats from Maharashtra to Kerala at an elevation of $900 \mathrm{~m}$ (Sathishkumar et al. 2012) and it is endemic to southern Western Ghats (Manasa and Chandrashekar 2015). Typically, this species is considered to be a potential medicinal plant as it possesses antimicrobial activity, antioxidant and is used in the treatment of the nervous disorder, diabetics, chronic bronchitis, lymphocytic leukaemia, snake bite; respiratory and skin problems (Sukumaran and Raj 2008; Sathishkumar and Baskar 2012). Besides these medicinal uses, T. alternifolia also consists of several secondary metabolites including alkaloids, flavonoids, steroids, tannins, glycosides and resins (Srivastava et al. 2001; Roy et al. 2002; Sathishkumar et al. 2008).

Anatomical investigations help in understanding the phylogenetic interactions as well as the physiological progression (Yeung 1998; Liu and Zhu 2011) and support in the identification of plants when floral characteristics are unavailable (Dengler 2002). The anatomy of vegetative parts of certain species of Apocynaceae has been examined. However, most of these studies have examined only the foliar anatomy and the stem and root anatomy of Apocynaceae is not well studied. Duarte and Larrosa (2011) examined the anatomical features of leaf and stem in Mandevilla coccinea (Hook \& Arn.) Woodson and reported uniseriate epidermis with thick and striate cuticle, paracytic stomata on both the leaf surfaces, dorsiventral mesophyll and collateral vascular bundles in leaves; and cambium formation, sclerenchymatous sheath with non-lignified fibers, bicollateral vascular bundles, large parenchymatous pith with amyloplasts in the stem; and occurrence of laticifers and phenolic compounds in both stem and leaf. A comparative study on the anatomical characters of Nerium oleander L. and Catharanthus roseus 
(L.) G. Don leaf by Abdalla et al. (2016) revealed that the dorsiventral leaf consisted of a single-layered epidermis with sparse epidermal hairs in C. roseus and isobilateral leaves, four-layered epidermis bearing numerous epidermal hairs, presence of sunken stomata and calcium oxalate crystals in N. oleander.

Although literature is available on the morpho-anatomical features of leaf and stems of various genus of Apocynaceae (Rio et al. 2005; Larrosa and Duarta 2006; Maciel et al. 2010; Abdalla et al. 2016), anatomical description of the genus Tabernaemontana is very limited. Omino (1996) investigated the leaf anatomy 37 species in 26 genera of Apocynaceae including four species of Tabernaemontana (Tabernaemontana pachysiphon Stapf, Tabernaemontana elegans Stapf, Tabernaemontana stapfiana Britten, Tabernaemontana ventricosa Hochst. ex A.DC) occurring in Africa and observed paracytic stomata in all the examined species, single-layered epidermal cells on both the foliar surfaces except in T. pachysiphon (1-2 layered), bifacial mesophyll with numerous intercellular spaces, collenchymatous cells in the ground tissue of midrib, clustered crystals in both the epidermal layer, mesophyll and in the ground tissue of midrib region in $T$. ventricosa; numerous solitary crystals in lower epidermis and star-shaped crystals in palisade layer of T. pachysiphon whereas small star-like crystals were reported in phloem parenchyma of $T$. stapfiana. The vascular bundles were deep V-shaped in all four species of Tabernaemontana (Omino 1996). The wood anatomy of Tabernaemontana eglandulosa Stapf, and Tabernaemontana siphilitica (L.f) Leeuwenb., revealed distinct growth rings, vessel grouping in radial multiples, vessels with sporadically double simple perforations, septate fibers with simple to minutely bordered pits and axial parenchyma were either scarce or absent (Lens et al. 2008).

Guidoti et al. (2015) studied the morpho-anatomical characters of Tabernaemontana catharinesis A.DC leaves and observed uniseriate epidermis devoid of trichomes, six to seven layers of angular collenchyma, thin-walled parenchymatous cortex, and bicollateral vascular bundle. Tabernaemontana catharinesis stem possessed uni-stratified epidermis, angular collenchyma cells and fibers in the cortical region and the secondary growth revealed the presence of periderm and fibers in external phloem patches. The petiole in T. catharinesis had uni-stratified epidermis, thick cuticle, and angular collenchyma adjacent to the epidermis and bicollateral vascular arrangement (Guidoti et al. 2015). As T. alternifolia is an endemic plant with high medicinal value, it is important to conserve this species through various means including vegetative propagation. Therefore, anatomical investigation of vegetative parts like leaf, stem and root could be helpful in understanding the regeneration of the plant dur- ing vegetative propagation. In addition, information on vegetative anatomy of Tabernaemontana species is scanty. Therefore, the present study was carried out to investigate the vegetative characters including the leaf, petiole, stem and root in T. alternifolia.

\section{Material and methods}

Samples of leaf, stem, and roots were collected from mature plants of T. alternifolia during the month of February 2019 from Nadugani, Gudalur taluk of Nilgiri district, Tamilnadu, India. The latitude and longitude of the study site are $11.4718^{\circ} \mathrm{N}$ to $76.4107^{\circ} \mathrm{E}$ at an elevation of $\sim 1000$ $\mathrm{m}$ a.s.l., and the average rainfall is $2020 \mathrm{~mm}$. The plant specimens were authenticated by Botanical Survey of India, Southern circle and a voucher was deposited in the Bharati Herbarium, Department of Botany, Bharathiar University, Coimbatore, India (accession number: 007744). The collected plant samples were transferred to the laboratory by placing the samples in an ice-box. The plant materials were washed with distilled water and preserved in formalin-acetic acid-alcohol (FAA) solution until processing. The leaf and petiole sections were taken from the fully developed $5^{\text {th }}$ leaf from the top. Stem sections were taken at the $5^{\text {th }}$ internode from the shoot tip and root sections were taken from $5 \mathrm{~cm}$ from the root tip. The preserved material (leaf, stem, petiole and root) of T. alternifolia were freehand sectioned using a sharp razor blade for the histological observations using different types of stains like safranin, phloroglucinol-HCl, and toluidine blue $\mathrm{O}$ to identify the cell inclusions such as cutin, suberin and lignin (Gurav et al. 2014). Around $1 \mathrm{~cm}$ square leaf pieces were placed in Jeffrey's maceration solution for 72 hours at $35^{\circ} \mathrm{C}$ for the observation of the epidermal layer (Kigkr 1971). The specimens in Jeffrey's fluid were later washed, stained with safranin and examined under an Olympus BX51 light microscope attached with a fluorescence setup (Olympus, U- RFL-T, U-25 ND 25 neutral density filter).

A calibrated ocular scale was used to measure the dimensions of the cells and the size of the different regions in the sections. The variables measured include the thickness of cuticle, the pore size of stomata, the length and width of the epidermis, collenchyma cells, palisade and spongy parenchyma cells, cortex, sclerenchymatous fibers and vascular bundles and pith cells. Images and autofluorescence of the observed specimens were captured with a ProgRes 3 camera fitted to the Olympus BX 51 light microscope. The stomatal index (SI \%) was calculated according to Salisbury (1927) using the formula (S/S+E) $\times 100$ where $S$ and $E$ denotes the number of stomata and epidermal cells respectively. All the observations are 
presented either as an average value or range (minimum value and maximum values) or average \pm standard error. Two dimensional values are presented as length $\times$ breadth .

\section{Results}

\section{Leaf}

Leaves are hypostomatic containing stomata only on abaxial surface and the adaxial surface is devoid of stomata (Fig. 1a,b). The stomata are of the paracytic type with two subsidiary cells parallel to the guard cells (Fig.1c). The cell dimensions of subsidiary cells and guard cells are respectively $26.75 \pm 0.91 \times 10.5 \pm 0.89 \mu \mathrm{m}$ and 22.75 $\pm 1.17 \times 7.5 \pm 0.64 \mu \mathrm{m}$. The stomatal pore measures 13.5 $\pm 0.55 \times 2.75 \pm 0.25 \mu \mathrm{m}$. The leaf consists of both adaxial and abaxial epidermis covered by a thin cuticle. The cuticle on the adaxial surface $(5 \mu \mathrm{m})$ is $25.85 \%$ thicker than the cuticle on the abaxial surface $(3 \mu \mathrm{m})$. The average stomatal index is $8.76 \%$. The upper and lower epidermis is uniseriate, consisting of a compactly arranged square to rectangular thin-walled parenchymatous cells (Fig. $1 \mathrm{~g}$ ). The length and width of epidermal cells of the upper and lower surface of the leaves are respectively $16.20 \pm$ $0.43 \times 25.62 \pm 0.74 \mu \mathrm{m}$ and $18.08 \pm 0.45 \times 24 \pm 0.62 \mu \mathrm{m}$. Hypodermis on the abaxial surface is 5-6 layered and is composed of angular collenchyma cells whereas on the adaxial side, hypodermal cells are 7-8 layered (Fig. 1e). The adaxial and abaxial collenchyma cells measures $16.20 \pm$ $0.43 \times 25.62 \pm 0.73 \mu \mathrm{m}$ and $20.6 \pm 1.17 \times 15.66 \pm 0.82 \mu \mathrm{m}$, respectively. The mesophyll is dorsiventral differentiated into palisade and spongy parenchyma cells. The palisade parenchyma is 2-3 layered and composed of thin-walled parenchymatous cells measuring $16.5 \pm 1.18 \times 11.75 \pm$ $0.65 \mu \mathrm{m}$. The palisade parenchyma is followed by $8-10$ layered spongy parenchyma cells bearing large intercellular spaces. The length and width of spongy parenchyma cells are $23.5 \pm 1.79 \times 20.75 \pm 1.13 \mu \mathrm{m}$. Silica bodies are present in both palisade and spongy parenchyma cells. In cross-section, the leaf midrib is biconvex. A sub-epidermal layer comprising of 14-18 layered thin-walled parenchyma cells are observed on both adaxial and abaxial sides (Fig. 1d). This region is characterized by the presence of thick-walled fibers (Fig. 1h), lactiferous cells and silica bodies. A V-shaped bicollateral vascular bundle is present in the midrib region. Xylem consists of metaxylem and protoxylem vessels. The metaxylem and protoxylem cells measures $30.5 \pm 0.78 \times 25.25 \pm 0.53 \mu \mathrm{m}$ and $14.12 \pm$ $0.32 \times 14.37 \pm 0.39 \mu \mathrm{m}$, respectively. The protoxylem is oriented towards the upper epidermis and metaxylem is located towards the lower epidermis. Xylem is surrounded by internal and external phloem (Fig. 1f). The internal phloem forms a continuous strand (Fig. 1i) whereas, the

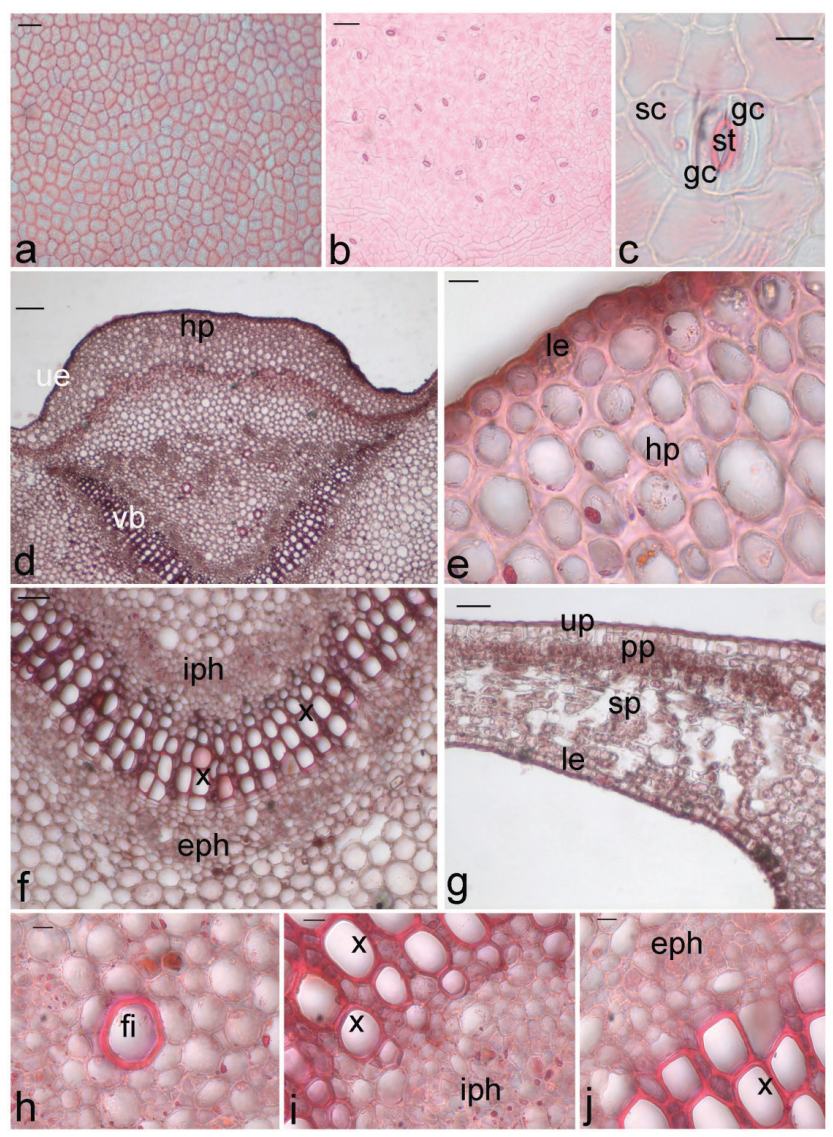

Figure 1. Vegetative anatomy of Tabernaemontana alternifolia leaf (a-j). a. Epidermal peeling of the adaxial surface of the leaf; $\mathbf{b}$. Abaxial surface showing the distribution of stomata; $\mathbf{c}$. Stomata with guard cells arranged parallel to the subsidiary cells; $\mathbf{d}$. Transverse section (T.S.) of leaf along the midrib region showing upper epidermis, hypodermis and vascular bundle; e. Lower epidermis covered by a thin cuticle, and collenchymatous hypodermis; f. Bicollateral vascular bundles, xylem surrounded by internal phloem and external phloem; g. Leaf lamina uniseriate upper epidermis, lower epidermis, palisade parenchyma and spongy parenchyma; $\mathbf{h}$. Thick-walled fibers; i. Internal phloem adjacent to xylem cells; j. External phloem and xylem.

st = stomata, $\mathrm{gc}=$ guard cell, $\mathrm{ue}=$ upper epidermis, $\mathrm{hp}=$ hypodermis, $\mathrm{vb}=$ vascular bundle, le = lower epidermis, $x=x y l e m, i p h=$ internal phloem, eph = external phloem, $\mathrm{pp}=$ palisade parenchyma, $\mathrm{sp}=$ spongy parenchyma, $\mathrm{fi}$ $=$ sclerenchymatous fiber. Scale bars $=50 \mu \mathrm{m}$.

external phloem appears as patches or small groups (Fig. 1j). The xylem arches range between 40 and 43 .

\section{Petiole}

The petiole is a flattened arch and lightly winged at the edges on the adaxial side in transverse section. The epidermis is single-layered with a compactly arranged round to oval thin-walled parenchymatous cells measuring $15.3 \pm 0.56 \times 11.2 \pm 0.25 \mu \mathrm{m}$ and covered by $2-3 \mu \mathrm{m}$ thick smooth cuticle (Fig. 2a). The hypodermis is a continuous band of 7-8 layered angular collenchyma cells measuring 
$35.75 \pm 2.29 \times 28 \pm 2.49 \mu \mathrm{m}$ (Fig. 2 c). Laticifers occur in the hypodermis. Around 12-16 cell layers of thin-walled parenchyma cells enclosing triangular or rectangular intercellular spaces subtends the hypodermis (Fig. 2b). Silica bodies and thick-walled fibers are present in the parenchymatic layer (Fig. 2d). The length and width of the parenchyma cells are $42.25 \pm 3.90 \times 43.5 \pm 2.83 \mu \mathrm{m}$. Vascular bundles are bicollateral and U-shaped. Xylem consists of protoxylem and metaxylem that measures $24.5 \pm 1.29 \times 22.5 \pm 0.55 \mu \mathrm{m}$ and $11.25 \pm 0.55 \times 11.5 \pm$ $0.85 \mu \mathrm{m}$, respectively. The protoxylem is oriented towards the epidermis. Xylem is surrounded by small patches of external and internal phloem (Fig. 2e,f). The external phloem patches measures $44.25 \pm 2.07 \times 47.25 \pm 4.17 \mu \mathrm{m}$ and the internal phloem patches measure $37.75 \pm 2.09 \times$ $39 \pm 2.77 \mu \mathrm{m}$.

\section{Stem}

The stem is circular in outline (Fig. 3a). The cuticle is

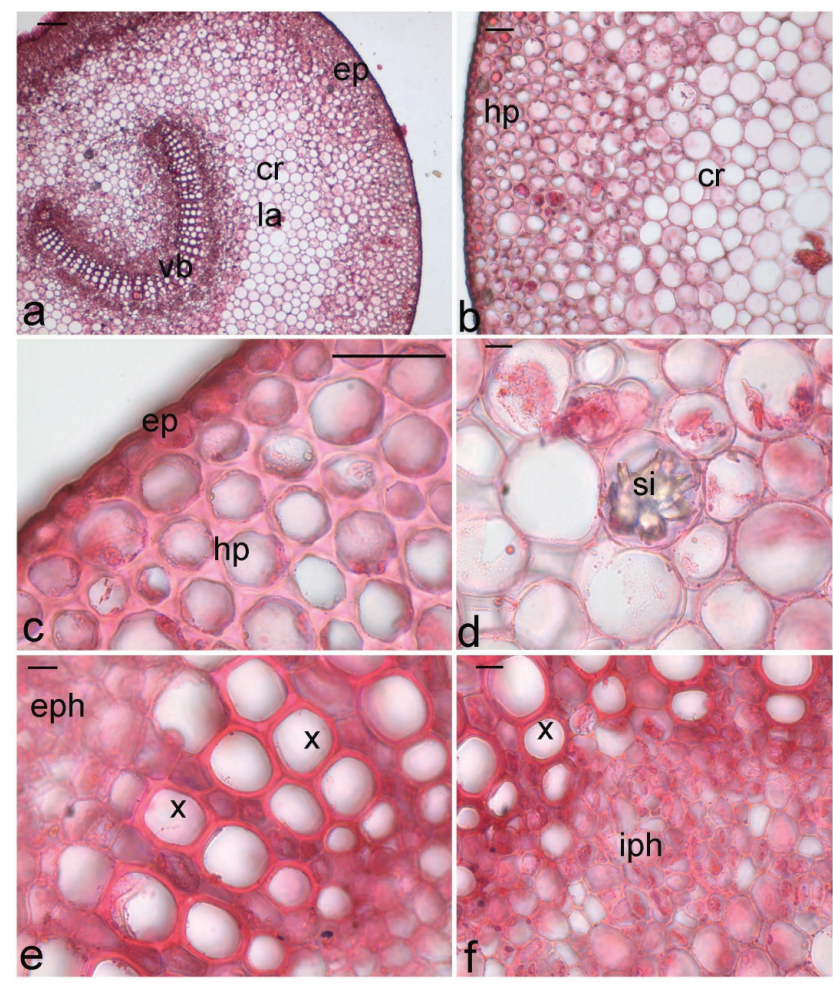

Figure 2. Vegetative anatomy of Tabernaemontana alternifolia petiole (a-f). a. Transverse section (T.S.) of petiole showing epidermis, cortex, laticifers and U-shaped vascular bundle; $\mathbf{b}$. hypodermis and cortex; c. Uniseriate epidermis and hypodermis; $\mathbf{d}$. Silica bodies in the cortical region, e,f. Vascular bundle showing xylem bordered by external phloem and internal phloem.

ep = epidermis, $\mathrm{cr}=$ cortex, $\mathrm{la}=$ laticifers, $\mathrm{vb}=$ vascular bundles, $\mathrm{hp}=$ hypodermis, si = silica bodies, eph = external phloem, iph = internal phloem, $\mathrm{x}=$ xylem. Scale bars $=50 \mu \mathrm{m}$.

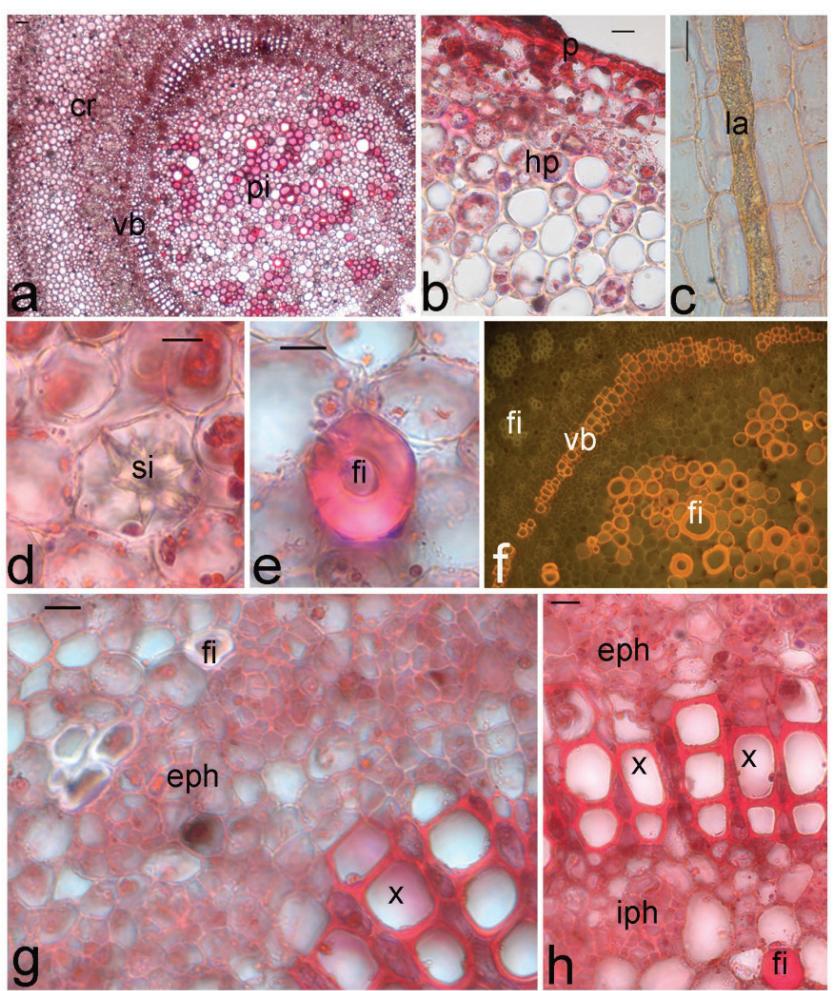

Figure 3. Vegetative anatomy of Tabernaemontana alternifolia stem (a-h). a. Transverse section (T.S.) of the stem showing periderm, bicollateral vascular bundle and pith; $\mathbf{b}$. Periderm and hypodermis made up of angular collenchyma cells; c. Longitudinal section (L.S) of the stem showing non- articulated laticifers; $\mathbf{d}$. Silica bodies in cortex; e. Thick-walled sclerenchymatous patches and fibers; f. Fluorescent image showing deposition of lignin in vascular bundles, sclerenchymatous fibers and sclerenchymatous fibers patches; $g$. Vascular bundles with xylem enclosed by external phloem and sclerenchymatous fibers; $\mathbf{h}$. Xylem covered by external phloem and internal phloem and fibers in the pith region.

$\mathrm{p}=$ periderm, $\mathrm{vb}=$ vascular bundle, $\mathrm{hp}=$ hypodermis, la = laticifers, $\mathrm{si}=$ silica bodies, $\mathrm{fi}=$ sclerenchymatous patches and fibers, $\mathrm{x}=\mathrm{xylem}$, eph $=$ external phloem, iph $=$ internal phloem, $\mathrm{pi}=$ pith. Scale bars $=50 \mu \mathrm{m}$.

smooth and 4-5 $\mu \mathrm{m}$ thick. The periderm is three-layered forming an outer layer and consists of loosely arranged thin-walled parenchymatous cells. The hypodermis is composed of 5-6 layers of angular collenchyma cells measuring $16.3 \pm 0.50 \times 14.15 \pm 0.37 \mu \mathrm{m}$. Idioblasts comprising of phenolic compounds are observed in the collenchymatic hypodermis (Fig. 3b). The parenchymatous cortex is 11-13 layered with cells measuring $30.25 \pm 0.72$ $\times 30.2 \pm 0.84 \mu \mathrm{m}$. Non-articulated laticifers, silica bodies and thick-walled fibers occur in the parenchymatic cortical cells which enclose triangular or rectangular or squarish intercellular spaces (Fig. 3c-e). The sclerenchymatous fibrous patches surrounding the vascular bundles are irregular and measures $67.7 \pm 2.30 \times 64.1 \pm$ $2.33 \mu \mathrm{m}$ and cells with lignin thickened walls (Fig. 3f). 
The vascular bundles are bicollateral and oval-shaped. The cambial zone consists of 2-3 rows of thin-walled small rectangular and meristematic cells arranged radially. The external and internal phloem are arranged in small groups or patches adjoining the xylem (Fig. 3g,h). The internal and external phloem patches measures 34.5 $\pm 1.95 \times 38.5 \pm 1.95 \mu \mathrm{m}$ and $38.33 \pm 1.51 \times 48.33 \times 2.01$ $\mu \mathrm{m}$, respectively. The vessels of the metaxylem measure $41.95 \pm 0.86 \times 32.2 \pm 0.65 \mu \mathrm{m}$ and the protoxylem cells measure $20.1 \pm 0.68 \times 14.9 \pm 0.47 \mu \mathrm{m}$. Pith is composed of thin-walled parenchyma cells with intercellular spaces. Fibers, laticifers and silica bodies occur in the pith region (Fig. 3a). The pith cells measure $50.5 \pm 5.51 \times 53.83 \pm$ $6.11 \mu \mathrm{m}$. The anatomical features of the mature stem are almost similar to that of the young stem except with few differences. The epidermal layer forms the outer layer in young stems and sclerenchymatous sheath consisting of fibers around the stellar region in mature stems is absent in the young stems. Moreover, the epidermis in young stem is replaced by the periderm in the older stems.

\section{Root}

The root appears circular in transverse section (Fig. 4a). Unicellular root hairs are present. The root hair measures $45.5 \pm 3.6 \times 12.6 \pm 0.45 \mu \mathrm{m}$. The epidermis is uniseriate, compactly arranged, and composed of oval to round shaped thin-walled parenchymatous cells (Fig. 4b). The cell dimensions of epidermal cells are $33.66 \pm 2.24 \times 39.23$ $\pm 2.38 \mu \mathrm{m}$. Cortex is $16-18$ layered, made up of thin-walled larger to smaller circular to oval-shaped parenchymatic cells enclosing triangular or squarish intercellular space. The cells in the cortical region measure $36.45 \pm 1.26 \times$ $44.83 \pm 2.03 \mu \mathrm{m}$. Silica bodies and thick-walled fibers occur in the cortex (Fig. 4a). The length and width of fibers are $36.66 \pm 2.24 \times 39.23 \pm 2.38 \mu \mathrm{m}$. Endodermis and pericycle are indistinct. Vascular bundles are arranged radially. Xylem is exarch. Xylem and phloem cells are differentiated by conjunctive tissue made up of parenchymatous cells (Fig. 4e). Xylem arches are 14-16 and the stele bears pitted water storage cells, and cells with lignin thickened walls (Fig. 4d,f). The water-storage cells measure $17.00 \pm 1.27 \times 11.05 \pm 0.87 \mu \mathrm{m}$. Pith is absent.

\section{Discussion}

The vegetative anatomy of T. alternifolia revealed certain variations in their anatomical traits when compared to other members of the Apocynaceae family. Trichomes are absent in leaves of T. alternifolia as reported in other species of Tabernaemontana (Omino 1996; Guidoti et al. 2015). However, trichomes have been reported in members of the Apocynanceae like Mandevilla velutina (A.DC.) Woodson and N. oleander (Santos et al. 2009; Maciel et

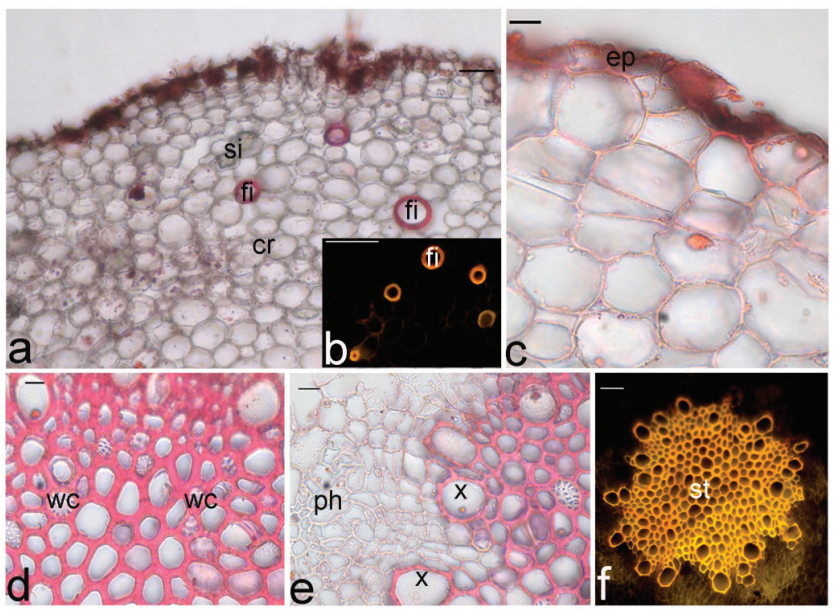

Figure 4. Vegetative anatomy of Tabernaemontana alternifolia root (a-f) a. Transverse section (T.S.) of root showing epidermis, sclerenchymatous fibers, silica bodies in the cortex $\mathbf{b}$. Fluorescent image (insert) showing deposition of lignin in sclerenchymatous fibers, c. Epidermis, d. Pitted water-storage cells in the stelar region, e. vascular bundles with xylem and phloem, f. Fluorescent image of stele indicating the presence of lignin deposition. Scale bars $=50 \mu \mathrm{m}$.

ep = epidermis, $\mathrm{fi}=$ sclerenchymatous fiber, $\mathrm{si}=$ silica bodies, $\mathrm{cr}=$ cortex, $\mathrm{wc}$ $=$ water-storage cells, $x=$ xylem, $\mathrm{ph}=$ phloem, st $=$ stele. Scale bars $=50 \mu \mathrm{m}$.

al. 2010). The hypostomatic leaves and paracytic stomata in T. alternifolia are similar to those reported by Omino (1996) in T. stapfiana, T. pachysiphon, T. ventricosa and T. elagans. However, in contrast to the observation of the present study, amphistomatic leaves were reported in $T$. catharinensis (Guidoti et al. 2015) and M. coccinea (Durate and Larrosa 2011). The presence of stomata on the abaxial surface of the leaf in T. alternifolia helps to minimize the water loss (Mbagwu et al. 2008). Moreover, paracytic type of stomata is the characteristic feature of the genus Tabernaemontana (Metcalfe and Chalk 1950, 1988; Omino 1996). The stomatal index of $73.42 \%$ in T. alternifolia is less than that of the stomatal index reported in Tabernaemontana divaricata (L.) R.Br. ex Roem. \& Schult. However special type of stomata called giant stomata is reported in T. divaricata (Gowramma and Sultan 2018) is absent in leaves of T. alternifolia. The differences in the stomatal index could be due to the physiological responses to various environmental factors (Adegbite 2008; Aworinde et al. 2012). Cuticle acts as an apoplastic barrier against water loss and also prevents the entry of other solutes from external sources into the plant tissue (Yeats and Rose 2013). Leaves of T. alternifolia possessed thin-cuticle over the leaf that contradicts studies where a thick cuticle has been reported to cover the leaves in Tabernaemontana species (Omino 1996; Guidoti et al. 2015). However, Mayberry (1937) observed thin cuticle covering the leaves of Amsonia tabernaemontana Walter. In contrast to the observations 
of the present study, a bilayered epidermis covering both the leaf surfaces has been reported in T. pachysiphon and T. stapfiana (Omino 1996).

The mesophyll is dorsiventral in T. alternifolia which is similar to the other members of the Apocynaceae family (Metcalfe and Chalk 1950). The ecological anatomy of the tree species suggested that the degree of mesophyll differentiation mostly depends on the degree of exposure to the sun (Hanson 1917; Ryder 1954). The mesophyll in T. alternifolia resembles that of $T$. catharinensis consisting of 2-3 layers of palisade parenchyma cells (Guidoti et al. 2015). On the contrary, palisade parenchyma was 3-4 layered in T. stapfiana (Omino 1996). The spongy parenchyma cells in T. alternifolia are similar to those of other Tabernaemontana species (Omino 1996; Guidoti et al. 2015). Laticifers and crystals present in mesophyll, multilayered hypodermis and bicollateral vascular bundles in T. alternifolia are the common characteristic features of Apocynaceae (Matclafe and Chalk 1950; Omino 1996).

The petiole is flattened arch-shaped with small projections in T. alternifolia is similar to those observed in T. catharinensis. Nevertheless, concave-convex structured petiole was reported in Forsteronia glabrescens Müll.Arg. and $M$. coccinea of Apocynancea family (Larrosa and Duarte 2006; Durate and Larrosa 2011). The presence of non-lignified fibers in F. glabrescens adjacent to the internal phloem is in accordance with the observations of the present study (Larrosa and Duarte 2006). Angular collenchyma cells present in the hypodermal region of $T$. alternifolia is similar to those in T. catharinensis (Guidoti et al. 2015) and contrastingly, annular collenchyma was noted in M. coccinea (Duarte and Larrosa, 2011). Silica bodies and laticifers observed in T. alternifolia are similar to those of T. catharinensis. The presence of silica bodies in T. alternifolia could prevent from collapsing of the plant during drought (Matcalfe and Chalk 1979). In the present study, vascular bundles are U-shaped and bicollateral. Similar observations were reported in T. elegans, T. stapfiana and T. catharinensis (Omino 1996; Guidoti et al. 2015). In contrast to the results of the present study, V-shaped, shallow and curved arc-shaped bicollateral vascular bundles were reported in Himatanthus sucuuba (Spruce ex Müll.Arg.) Woodson, Voacanga thouarsii Roem. \& Schult., Rauvolfia mombasiana Stapf and Strophanthus barteri Franch (Larrosa and Duarte 2005; Omino 1996).

The secondary growth in T. alternifolia stem reveals the formation of the periderm in the outermost layer that is in line with the observations of Larrosa and Duarte (2006) and Guidoti et al. (2015) in H. sucuuba and T. catharinensis. Nevertheless, an incipient secondary growth in $M$. coccinea stem possessed single-layered epidermis covered with thick striated cuticle (Duarte and Larrosa, 2011). Periderm forms a protective tissue during the secondary growth replacing the epidermis (Evert 2006). The angular collenchyma cells, sclerenchymatous sheath consisting of lignified thick-walled fibers enclosing the vascular bundles in T. alternifolia is as same as T. catharinensis (Guidoti et al. 2015). The thick-walled fibers commonly found in patches, provides rigidity and flexibility to the plants (Esau 1974; Costa et al. 2006; Scatena and Scremin-Dias 2006). Similar to T. alternifolia, the stem of T. catharinensis in transverse section showed the presence of fibers and laticifers in the cortical region (Guidoti et al. 2015). Moreover, the distribution of laticifers differs among the species, for example, laticifers occur only in the cortex in Himatanthus lancifolius (Müll.Arg.) Woodson (Baratto et al. 2010a) whereas, in Rauvolfia sellowii Stapf, it was reported in the phloem cells and marrow (Baratto et al. 2010b). The laticifers produce latex due to physical damage and consist of varied latex compounds that protect the plants against herbivores or pathogens (Ramos et al. 2019). Occurrence of laticifers is very common in Apocynaceae family (Metcalf and Chalk 1950) and may be branched or unbranched or non-articulated (Esau 1977; Mahlberg 1993). Laticifers in the T. alternifolia are non-articulated as observed in Tabernaemontana coronaria Willd (Rao and Malaviya 1966). However, articulated laticifers have been reported in the other member of Apocynaceae like $T$. catharinensis (Canaveze and Machado 2016), Mandevilla atroviolacea (Stadelm.) Woodson (Lopes et al. 2009) and Allamanda blanchetii A. DC. (Gama et al. 2017)

Silica bodies were present in cortex and pith regions of T. alternifolia. However, the idioblasts containing silica bodies were not observed in T. catharinensis (Guidoti et al. 2015). Contrastingly to the observations of T. alternifolia in the present study, starch grains were reported in some species of Apocynaceae (El-Kashef et al. 2015; Duarte and Larrosa 2011). The intraxylary or internal phloem in $T$. alternifolia is a common feature of Apocynaceae family. In the present study, internal phloem existed as an isolated strand forming a group of patches similar in other species of the family, like A. tabernaemontana (Mayberry 1937) and $M$. coccinea (Larrosa and Duarte 2011). In contrast to the results of the present study, internal phloem formed a continuous ring in N. oleander (Maciel et al. 2010). According to Metcalfe and Chalk (1950), internal phloem commonly occurs in a continuous ring or isolated groups in the Apocynaceae. The function of internal phloem in stems of climbers includes prevention of breakage when stems are coiled or twisted and enhance the mechanical flexibility of stems (Sckench 1893). However, in trees Premakumari et al. (1985) reported that internal phloem help in the translocation of photosynthates. Therefore, the presence of internal phloem in T. alternifolia stem may also perform certain functions like translocation of growth substances. 
The anatomy of the root in Apocynaceae is relatively less explored when compared leaves and petiole. Tabernaemontana alternifolia had uniseriate epidermis. The cortex in T. alternifolia is 16-18 layered in contrast to Carissa macrocarpa (Eckl.) A.DC. where the cortex is only 12-15 layered (Allam et al. 2016). However, the indistinct endodermis of T. alternifolia resembles with endodermis reported in C. macrocarpa. Starch grains were absent in the roots of T. alternifolia as reported in other species of Apocynaceae (Appezzato-da-Glória and Estelita 1997; Boutebtoub et al. 2009; Allam et al. 2016). Laticifers are one of the important characteristic features of Apocynaceae. Nevertheless, in the present study, although, laticifers were observed in leaves, petiole and stem of T. alternifolia, it was absent in the roots. Pitted water-storage cells could help T. alternifolia during the xerophytic or drought conditions. Vascular bundles are arranged radially in T. alternifolia. The pith was absent in T. alternifolia root similar to that reported in C. macrocarpa (Allam et al. 2016). The lignin deposition in stelar region as supported by the auto fluorescence could also provide additional structural support to the plant (Willemse 1989).

\section{Conclusion}

The present study revealed that the presence of paracytic stomata restricted to abaxial surface of the leaf, thin cuticle on adaxial and abaxial side in leaves, thick-walled sclerenchymatous patches, isolated internal phloem strands in stems; water storage cells, and deposition of lignin in root stelar region could contribute to the identification of this endemic plant.

\section{Acknowledgement}

We thank Dr. C. Murugan, Director, Botanical Survey of India, Southern Circle, Coimbatore, Tamil Nadu, India for authenticating the specimens and Dr. C. Udhayavani for assistance during plant collection. We thank the University Grants Commission (UGC)-Special Assistance Programme [Ref No:F.5-16/2016/DRS1 (SAP-II)] for providing financial assistance during the course of this work. Yuvarani Seenu thanks DST-PURSE scheme (Phase-II) for the award of Project fellowing (BU/ DSTPurse (II) / APPOINTMENT / 233).

\section{References}

Abdalla MM, Eltahir AS, El-Kamali HH (2016) Comparative morph-anatomical leaf characters of Nerium oleander and
Catharanthus roseus family (Apocynaceae). EJBAS 3:68-73.

Adegbite AE (2008) Leaf anatomical studies in some species of the tribe Cichorieae (Asteraceae) in Nigeria. Comp Newsl 46:49-58.

Allam KM, El-Kader AMA, Mostafa MAH, Fouad MA (2016) Botanical studies of the leaf, stem and root of Carissa macrocarpa, (Apocynaceae), cultivated in Egypt. J Pharmacogn Phytochem 5:106-113.

Appezzato-da-Glória B, Estelita ME (1997) Laticifer systems in Mandevilla illustris and Mandevilla velutina Apocynaceae. Acta Soc Bot Pol 66:301-306.

Aworinde DO, Ogundairo BO, Osuntoyinbo KF, Olanloye OA (2012) Foliar epidermal characters of some Sterculiaceae species in Nigeria. Bayero J Pure Appl Sci 5 48-56.

Baratto LC, Hohlemwerger SVA, Guedes MLS, Duarte MR, Santos CAM (2010a) Himatanthus lancifolius (Müll. Arg.) Woodson, Apocynaceae: estudo farmacobotânico de uma planta medicinal da Farmacopeia Brasileira 1a edição. Rev Bras Farmacogn 20:651-658.

Baratto LC, Duarte MDR, Santos CADM (2010b) Pharmacobotanic characterization of young stems and stem barks of Rauvolfia sellowii Müll. Arg., Apocynaceae. Braz J Pharm Sci 46:555-561.

Boutebtoub W, Chevalier M, Mauget JC, Sigogne M, Morel P, Galopin G (2009) Localizing starch reserves in Mandevilla sanderi (Hemsl.) Woodson using a combined histochemical and biochemical approach. J Am Soc Hortic Sci 44:1879-1883.

Canaveze Y, Machado SR (2016) The occurrence of intrusive growth associated with articulated laticifers in Tabernaemontana catharinensis A. DC., a new record for Apocynaceae. Int J Plant Sci 177:458-467.

Costa CG, Callado CH, Coradin VTR, Carmello-Guerreiro SM (2006) Xilema. In Appezzato-da-Glória B, CarmelloGuerreiro SM, Orgs., Anatomia Vegetal. Viçosa, Editora da UFV. 129-154.

Dengler NG (2002) An integral part of botany. Am J Bot 89:369-374.

Duarte MR, Larrosa CRR (2011) Morpho-anatomical characters of the leaf and stem of Mandevilla coccinea (Hook. et Arn.) Woodson, Apocynaceae. Braz J Pharm Sci 47:137-144.

El-Kashef DF, Hamed ANE, Khalil HE, Kamel MS (2015) Triterpenes and sterols of family Apocynaceae). A review. J Pharmacogn Phytochem 4:21-39.

Esau K (1977) Anatomy of Seed Plants. Wiley, New York.

Esau K (1974) Anatomia das Plantas com Sementes. Editora Blucher, São Paulo.

Evert RF (2006) Esau's Plant Anatomy, Meristems, Cells, and Tissues of the Plant Body: their Structure, Function, and Development. John Wiley \& Sons, New Jersey.

Gama TDSS, Rubiano VS, Demarco D (2017) Laticifer development and its growth mode in Allamanda blanchetii 
A. DC. (Apocynaceae). J Torrey Bot Soc 144:303-313.

Gowramma B, Sultan B (2018) Comparative study of stomatal index at family level. J Bas App Res 8:1114-1129.

Guidoti DGG, Guidoti DT, Rocha CLMSC, Mourão KSM (2015) Morphoanatomic characterization of the stem and the leaf of Tabernaemontana catharinensis (Apocynaceae) and antimutagenic activity of its leaves. Bras Pl Med Campinas 17:667-679.

Gurav S, Tilloo S, Burade K (2014) Histological and histochemical staining techniques. In Gurav SS, Gurav NS, Eds., Indian Herbal Drug Microscopy. Springer, New York, 9-14.

Hanson HC (1917) Leaf structure as related to the environment. Am J Bot 4:533-559.

Ignacimuthu S, Ayyanar M, Sivaraman K (2006) Ethnobotanical investigations among tribes in madurai district of Tamil Nadu, India. J Ethnobiol Ethnomed 2:1-7.

Kigkr RW (1971) Epidermal and cuticular mounts of plant material obtained by maceration. Stain Technol 46:71-75.

Larrosa CRR, Duarte MDR (2005) Contribution to the anatomical study of the stem of Himatanthus sucuuba (Spruce ex Müll. Arg.) Woodson, Apocynaceae. Rev Bras Farmacogn 15:110-114.

Larrosa CRR, Duarte MR (2006) Anatomia foliar e caulinar de Forsteronia glabrescens, Apocynaceae. Acta Farm Bonaer 25:28-34.

Lens F, Endress ME, Baas P, Jansen S, Smets E (2008) Wood anatomy of Rauvolfioideae (Apocynaceae): a search for meaningful non-DNA characters at the tribal level. Am J Bot 95:1199-1215.

Liu W, Zhu XY (2011) Leaf epidermal characters and taxonomic revision of Schizophragma and Pileostegia (Hydrangeaceae). Bot J Linn Soc 165:285-314.

Lopes KLB, Thadeo M, Azevedo AA, Soares AA, Meira RMSA (2009) Articulated laticifers in the vegetative organs of Mandevilla atroviolacea (Apocynaceae, Apocynoideae). Botany 87:202-209.

Maciel VEO, Corrêa PG, Silva MD, Chagas MGS, Pimentel RMM (2010) Anatomia e histoquímica do caule e folha de Nerium oleander L. In X Jornada de Ensino Pesquisa e Extensão - JEPEX, 2010, Recife. Apresentação de trabalho. Resumo Expandid 42:585-598.

Mahlberg PG (1993) Laticifers: an historical perspective. Bot Rev 59:1-23.

Manasa DJ, Chandrashekar KR (2015) Antioxidant and antimicrobial activities of Tabernaemontana heyneana WALL. An endemic plant of Western Ghats. Int J Pharm Sci 7:311-315.

Mayberry MW (1937) Some anatomical features of Amsonia tabernaemontana. Trans Kans Acad Sci 40:75-81.

Mbagwu FN, Nwachukwu CU, Okoro OO (2008) Comparative leaf epidermal studies on Solanum marcocarpon and Solanum nigrum. Res J Bot 3:45-48.
Metcalfe CR, Chalk L (1950) Anatomy of the Dicotyledons. Clarendon Press, Oxford.

Metcalfe CR, Chalk L (1988) Anatomy of the Dicotyledons. Volume 1: Systematic Anatomy of the Leaf and Stem. Clarendon Press, Oxford.

Metcalfe CR, Chalk L (1979) Anatomy of the Dicotyledons Volume II: Wood Structure and Conclusion of the General Introduction. Clarendon Press, Oxford.

Omino EA (1996) Contribution to the leaf anatomy and taxonomy of Apocynaceae in Africa: the leaf anatomy of Apocynaceae in East Africa; a monograph of Pleiocarpinae (Series of revisions of Apocynaceae XLI). Backhuys Publisher, Leiden.

Premakumari D, Panikkar AON, Sobhana S (1985) Occurrence of intraxylary phloem in Hevea brasiliensis (Willd. ex A. Juss.) Muell. Arg. Ann Bot 55:275-277.

Ramos MV, Demarco D, da Costa Souza IC, de Freitas CDT (2019) Laticifers, latex, and their role in plant defense. Trends Plant Sci 24:553-567.

Rao AR, Malaviya M (1966) The non-articulated laticifers and latex of Tabernaemontana coronaria Willd. Proc Natl Acad Sci India B 32:233-242.

Rio MCS, Kinoshita LS, Castro MM (2005) Anatomia foliar como subsídio para a taxonomia de espécies de Forsteronia G. Mey. (Apocynaceae) dos cerrados paulistas. Braz J Bot 28:713-726.

Roy R, Grover RK, Srivastva S, Kulshreshtha DK (2002) A new stereoisomer of stem made nine alkaloid from Tabernaemontana heyneana Wall. Magn Reson Chem 40:474-476.

Ryder VL (1954) On the morphology of leaves. Bot Riv 20:263-267.

Salisbury EJ (1927) On the causes and ecological significance of stomatal frequency, with special reference to the woodland flora. Philos 216:1-65.

Santos MCA, Freitas SDP, Aroucha EMM, Santos ALA (2009) Anatomia e histoquímica de folhas e raízes de vinca (Catharanthus roseus (L.) G. Don). Rev Boil Ciên 9:24-30.

Sathishkumar T, Baskar R, Rajeshkumar M (2012) In vitro antibacterial and antifungal activities of Tabernaemontana heyneana Wall. leaves. J Appl Pharm Sci 2:107-111.

Sathishkumar T, Baskar R (2012) Evaluation of antioxidant properties of Tabernaemontana heyneana Wall. leaves. Indian J Nat Prod Resour 3:197-207.

Sathishkumar T, Baskar R, Shanmugam S, Rajasekaran P, Sadasivam S, Manikandan V (2008) Optimization of flavonoids extraction from the leaves of Tabernaemontana heyneana Wall. using L16 orthogonal design. Natr Sci 6:10-21.

Scatena VL, Scremin-Dias E (2006) Parênquima, colênquima e esclerênquima. In Appezzato-da-Glória B, CarmelloGuerreiro SM, Orgs., Anatomia Vegetal. Viçosa, Editora da UFV. 109-128. 
Schenck H (1893) Beiträge zur Biologie und Anatomie der Lianen, im Besonderen der in Brasilien einheimischen Arten. II. Beiträge zur Biologie der Lianen. Bot. Mitt. Tropen 5:1-271.

Srivastava S, Singh MM, Kulshreshtha DK (2001) A new alkaloid and other anti-implantation principles from Tabernaemontana heyneana. Planta Med 67:577-579.

Sukumaran S, Raj ADS (2008) Rare, endemic, threatened (RET) trees and lianas in the sacred groves of Kanyakumari district. Indian For 133:1254-1267.

Van Beek TA, Verpoorte R, Svendsen AB, Leewenberg AJM, Bisset NG (1984) Tabernaemontana L. (Apocynaceae): A review of its taxonomy, phytochemistry, ethnobotany and pharmacology.J Ethnopharmacol Lausanne 10:1-156.
Yeats TH, Rose JK (2013) The formation and function of plant cuticles. Plant Physiol 163:5-20.

Yeung E (1998) A beginner's guide to the study plant structure. Purdue University, Lafayatte, In Karcher SJ, Ed.,Tested Studies for Laboratory Teaching, Proceedings of the $19^{\text {th }}$ Workshop /Conference of the Association for Biology Laboratory Education(ABLE). 19:125-142.

Willemse MTM (1989) Cell wall autofluorescence. In Chesson A, Ørskov ER, eds., Physico-Chemical Characterisation of Plant Residues for Industrial and Feed Use. Springer, Dordrecht. 50-57. 
